\title{
Risk factors for the occurrence of new and chronic cases of subclinical mastitis in dairy herds in southern Brazil
}

\author{
L. L. Cardozo, ${ }^{* 1}$ A. Thaler Neto, ${ }^{*}$ G. N. Souza,† L. C. A. Picinin, ${ }^{*}$ N. C. Felipus, ${ }^{*}$ N. L. M. Reche, ${ }^{*}$ F. A. Schmidt, ${ }^{*}$ \\ D. Werncke, $\ddagger$ and E. E. Simon* \\ *Department of Animal Production and Food, University of Santa Catarina (UDESC), 88520-000 Lages, SC, Brazil \\ †Embrapa Dairy Cattle, 36038-330 Juiz de Fora, MG, Brazil \\ $\ddagger$ Department of Animal Science, Federal University of Rio Grande do Sul, 90040-060, Porto Alegre, RS, Brazil
}

\section{ABSTRACT}

The aim of this research was to evaluate the risk factors for new and chronic subclinical intramammary infections (IMI) using the monthly somatic cells count of dairy cows. The study took place at 30 dairy herds with approximately 1,700 cows in lactation. Data characterizing the dairy farms and their milking management were obtained from a survey questionnaire. The somatic cells count values from 2 consecutive months were used to classify cows as either healthy or with new or chronic infections. A chi-squared test was used in the analysis of subclinical IMI to evaluate associations between each independent variable, followed by logistic regression to estimate the risk of a new infection in healthy cows and of chronic infection in cows with new infections. Factors increasing the odds ratio of a cow developing a new case of subclinical mastitis were (1) cows with more than 3 lactations, (2) cows with a mean hyperkeratosis score above 3, (3) cows with the udder below the hock, (4) cows with very dirty udders, and (5) milking of infected animals before healthy cows. Factors increasing the risk of a subclinical chronic infection compared with new cases of subclinical mastitis were (1) a lack of regular maintenance of milking machinery, (2) cows over $100 \mathrm{~d}$ in lactation, and (3) cows with the udder on or below the hock. The risk factors identified in this study can be used in IMI control programs to reduce the frequency of new and chronic cases of subclinical mastitis.

Key words: dairy herd, intramammary infection, odds ratio, somatic cell

\section{INTRODUCTION}

Bovine mastitis is one of the main diseases affecting dairy herds worldwide (Ruegg and Pantoja, 2013). Mas-

Received September 29, 2014.

Accepted May 6, 2015.

${ }^{1}$ Corresponding author: leoleite_cav@hotmail.com titis causes many problems, both in the organoleptic and microbiological characteristics of the milk and in terms of drug costs, discarded milk, and early cow replacement (Halasa et al., 2007; Janzekovic et al., 2009; Geary et al., 2012). The SCC in milk is an important tool for the diagnosis of subclinical mastitis and is internationally accepted as a criterion for evaluating the health of a cow's mammary gland (Dohoo and Leslie, 1991; Bradley and Green, 2005; Ruegg, 2006; CicconiHogan et al., 2013). Monthly reports of a cow's SCC allows for the monitoring of the frequency, prevalence, and incidence of mastitis (Ruegg, 2003; Madouasse et al., 2010). The month-to-month monitoring of SCC in cows is an important tool for making decisions for the prevention of subclinical IMI (Schukken et al., 2003; Souza et al., 2011).

Several SCC parameters have been used to classify the health status of a cow's mammary gland (Dufour and Dohoo, 2013), whereas for studies with composite milk samples, the threshold of 200,000 cells $/ \mathrm{mL}$ is generally used for confirmation of disease with the goal of reducing diagnostic mistakes (Djabri et al., 2002; Schukken et al., 2003; Madouasse et al., 2010, Madouasse et al., 2012; Rhoda and Pantoja, 2012). A study of dairy herds in Ontario, Canada, found that the maximum limit of 200,000 cells $/ \mathrm{mL}$ resulted in a sensitivity between 73.0 and 89.0 and a specificity between 75.0 and 90.0 for the detection of disease prevalence (Dohoo and Leslie, 1991). In another study using the same SCC limit, Schepers et al. (1997) found a sensitivity and specificity of 74.5 and 89.6, respectively. Pantoja et al. (2009a) concluded that cows with SCC values above 200,000 cells/mL before drying-off had a higher risk of subclinical mastitis in the first month after calving. Pantoja et al. (2009b) observed a higher prevalence of clinical mastitis in animals with the mammary quarters classified as chronically infected (SCC >200,000 before drying-off and after calving) than in animals with mammary quarters classified as healthy (SCC $<200,000$ before drying-off and after calving). Souza et al. (2011) 
found that the risk of chronic infection was higher in cows of herds that had a high prevalence of subclinical mastitis (herds with SCC from the bulk tank higher than 750,000 cells $/ \mathrm{mL}$ ). Thus, month-to-month monitoring of the SCC values of individual cows is broadly used to estimate the mammary gland infection status on dairy farms (Cook et al., 2002). The use of a SCC threshold of 100,000 cells/mL have been proposed by some authors (Schwarz et al., 2010; dos Reis et al., 2011) for SCC of individual mammary quarters of cows. However, it should be noted that in composite samples, the value of SCC is diluted by the noninfected mammary quarters.

The analysis of mastitis risk factors can help identify measures to improve mammary gland health in dairy herds, and such analysis is often based on a combination of diagnosis and monitoring systems (Gambôa et al., 2004). Thus, the identification of risk factors associated with the occurrence of IMI can help improve programs for the prevention and control of mastitis in dairy herds (Olde Riekerink et al., 2006; Piepers et al., 2007). Many factors can influence SCC values, including milking management, parity, DIM, and even the month and season of the year (Laevens et al., 1997; Skrzypek et al., 2004; Osterås et al., 2006; Lievaart et al., 2007; Olde Riekerink et al., 2007; Cunha et al., 2008; Jansen et al., 2009). New methods of analysis have allowed researchers to identify with greater accuracy management practices that reduce the SCC level of individuals and of whole herds. In a review of 36 scientific papers, Dufour et al. (2011) observed that management practices usually associated with lower SCC values were the use of gloves by milkers during milking, periodic maintenance of milking machines, teat disinfection after milking, and milking cows with high SCC counts or clinical mastitis last. Cicconi-Hogan et al. (2013) observed that such management practices as monthly monitoring of SCC values, vaccination, and postmilking teat disinfection were associated with decreased SCC values for milk in bulk tanks.

Any mastitis prevention and control program should also consider the risk factors for mastitis associated with milking machines. Wenz et al. (2007), evaluating management practices in dairy herds, observed that the use of automatic cluster removers was associated with lower SCC values in bulk tank milk. Inadequate milking practices or poorly maintained equipment can also be related to the appearance of lesions at the ends of the teats (Capuco et al., 1994; Schukken et al., 2003). Sousa (2008) found the absence of automatic cluster removers to be highly associated with the occurrence of teat end lesions.
For each mammary gland infection status, specific risk factors are known (Schukken et al., 1990; Elbers et al., 1998; Schukken et al., 2003). However, studies of the risk factors for mastitis are never definitive because it is impossible to evaluate, in a single study, all the potential risk factors in a herd (Souza and Brito, 2011). Therefore, the present study aimed to evaluate risk factors for new cases of subclinical IMI and the persistence of such infections by using monthly SCC values of milk cows in dairy herds in southern Brazil.

\section{MATERIALS AND METHODS}

\section{Herds and Data}

The study was conducted in the western, midwestern, southern, and highland regions of the state of Santa Catarina, in southern Brazil, and involved 30 dairy farms enrolled in the DHI test of the Santa Catarina Association of Cattle Breeders (ACCB, Florianopolis, Brazil), with monthly information about milk yield, milk composition, and SCC of cow composite samples. This area of Brazil is composed of 2 regions, one with a humid subtropical climate with a hot summer and the other with a humid temperate climate with a temperate summer according to Köppen (EPAGRI, 2005). These regions have the greatest number of herds enrolled in the DHI test in the state.

The study involved 1,700 lactating cows, with 1,080 Holstein, 575 Jersey, and 45 Holstein $\times$ Jersey cross. The cows were milked 2 or 3 times a day in milking machines, with the milk stored in bulk tanks. On average the dairy farms had 47.1 lactating cows, whereas $13.3 \%$ of the herds had up to 20 cows, $36.7 \%$ had 21 to 40 cows, $26.7 \%$ from 41 to 60 cows, $13.3 \%$ from 61 to 80 cows, and just $10.0 \%$ had more than 80 dairy cows. The study used data from 11,159 DHI dairy assessment tests, conducted from December 2011 to November 2012, that recorded information about breed, parity, DIM, milk, SCC, and date of calving.

At the beginning of the experiment, a survey questionnaire was distributed to the dairy farmers to obtain information about their herd size, the structure of their farm, and factors related to mastitis (techniques used in the management of milking and milking facilities, drugs used, and the disposal of animals infected with mastitis). Three technical visits were made to each farm, from March to December 2012, at intervals of approximately $3 \mathrm{mo}$, to evaluate teat end hyperkeratosis, the depth and cleanliness of the udder, and to update the database containing information on lactating cows, as described herein. 


\section{Evaluation of Teat End Hyperkeratosis, Depth, and Cleanliness of the Udder}

On each technical visit to the farms, the condition of the teat ends of all of lactating cows was evaluated, after milking and before the application of postmilking teat disinfection, for a total of 3,090 data points for 1,608 cows. The severity of hyperkeratosis was evaluated using a scale from 1 to $4(1=$ teat end without a ring; $2=$ teat end with small ring just forming; $3=$ teat end with rough ring just forming; $4=$ teat end with a well-developed rough ring) according to the methodology described by Mein et al. (2001). The mean score of hyperkeratosis of the 4 teats of each cow was then calculated.

In 2 of the technical visits made to each farm, the udder depth of lactating cows was evaluated, providing 2,015 data points from 1,393 cows. Udder depth was evaluated before milking, and was estimated as the distance of the floor of the udder from the line of hock, using a scale from 1 to 3 ( $1=$ udder floor above the line of hock, 2 = udder floor on hock line, $3=$ udder floor below the line of the hock) as described by Coentrão et al. (2008). On the same visit to each farm, the cleanliness of the udder was also evaluated before milking, using a scale from 1 to $4(1=$ totally clean, $2=$ slightly dirty, $3=$ mostly dirty, $4=$ completely covered with dirt) using the method described by Schreiner and Ruegg (2003).

\section{Evaluation of the Dynamics of Subclinical Mastitis}

The infection status of subclinical mastitis for each cow during each month of the study was represented by a comparison of 2 consecutive months, evaluating the SCC of the current monthly DHI test in relation to the previous month, as described by Ruegg (2003). Infection was defined as a SCC value above 200,000 cells/ mL (Schukken et al., 2003; Madouasse et al., 2012; Dufour and Dohoo, 2013).

Cows were classified as healthy, newly infected, or chronically infected as described by Schukken and Kremer (1996); Malek and Santos (2008). This classification was done as follows: (1) healthy cows, SCC $<200,000$ cells $/ \mathrm{mL}$ in the previous month and SCC $<200,000$ cells/mL in the following month; (2) newly infected cows, SCC $<200,000$ cells $/ \mathrm{mL}$ in the previous month but $\mathrm{SCC}>200,000$ cells $/ \mathrm{mL}$ in the following month; and (3) chronically infected cows, SCC >200,000 cells/ $\mathrm{mL}$ in both of the 2 consecutive sample months.

\section{Statistical Analyses}

Using the status of subclinical mastitis, the risk of a cow developing a new case of subclinical mastitis was evaluated in relation to healthy cows and that of chronically infected cows was evaluated in relation to cows that had a new case of subclinical mastitis. To estimate these risks, the explanatory variables were classifieds into 3 groups. The first group of variables related to the individual cow characteristics, such as breed (Holstein, Jersey, or Holstein $\times$ Jersey cross), milk production per day (up to 20, 20 to 30 , or over 30 L), parity $(1,2,3$, or $>4$ ), DIM (up to 100,101 to 200, 201 to 300 , or over $300 \mathrm{~d}$ ), hyperkeratosis (1.0 to 3.0 or 3.1 to 4.0), udder depth (above the hock, on the hock, or below), and cleanliness of the udder (clean, slightly dirty, and dirty or very dirty). The second group of variables related to the milking management and mastitis control, including cleaning of the teats (always or when dirty vs. never), premilking teat disinfection (yes or no), drying the teats (yes or no), elimination the first 3 jets of milk (yes or no), use of strip cup (yes or no), postmilking teat disinfection (yes or no), use of the California Mastitis Test (always, monthly or sometimes, or never), milking cows with mastitis last (always or sometimes vs. never), use of teat sealant (yes or no), antimicrobial treatment of subclinical mastitis (yes or no), use of vaccines for mastitis (yes or no), use of gloves during milking (yes or no), and the use of pressure over the set of liners (yes or no).

The third group of variables related to the farm structure, which included the volume of milk production (up to $1,000,1,001$ to 1,500 , or over $1,500 \mathrm{~L} / \mathrm{d}$ ), the number of cows in lactation (up to 40,41 to 80 , or over 80 ), vacuum line (low or average), milking equipment maintenance (periodic or sporadic), season of the year $($ winter $=$ June-August; spring $=$ September-November; fall = March-May; summer $=$ December-February), and the payment for milk quality (received or not.).

Statistical analyses were performed in SPSS version 8.0 (SPSS, 1998). To estimate the risk of new and chronic infection, we used the logistic regression model described by Hosmer and Lemeshow (1989) and Frankena and Graat (1997), with the dependent variable being the classification of cows by SCC. Explanatory variables included in the model were those associated with the characteristics of herds, cows, management procedures, milk production, teat end hyperkeratosis, and udder cleanliness. These explanatory variables were selected using bivariate analyses with the chisquared test. Those variables included in the logistic regression model were those that showed significant ties to the subclinical mastitis status as determined by the chi-squared test and $P<0.05$.

To identify the logistic regression model with the best fit in each group of explanatory variables (animal characteristics, milking management and mastitis control, 
and farm structure), we used the forward conditional command, which estimated the risk of a new or chronic infection predicted by each explanatory variable in the form of an odds ratio (OR). After identifying the risks for each group of explanatory variables, these variables were used to identify the final logistic regression model with the best adjustment for new or chronic infection, creating a model that incorporated all the most important characteristics that had been previously identified.

\section{RESULTS}

The mean SCC score, across all cows tested, was 494,000 cells/mL. Given the maximum limit of 200,000 cells $/ \mathrm{mL}$ established for the purposes of our study, we concluded that only $43.3 \%$ of cows were in good health at any given time.

\section{Explanatory Variables Related to the Individual Characteristics of the Cows}

When analyzed separately, all the explanatory variables significantly affected the risk that healthy cows would develop new cases of subclinical mastitis, as determined by chi-squared test. A significant relationship between the proportion of new cases of IMI due to the increase of parity and stage of lactation of cows, especially those with more than 4 births or greater than 300 DIM $(P<0.001)$. We also observed that hyperkeratosis of the teat ends and with pendulous $(P<0.001)$ or dirty udders $(P<0.01)$ were associated with increased number of subclinical cases of mastitis.

We observed that Jersey cows, as well as animals with less than $20 \mathrm{~L} / \mathrm{d}$, showed a higher proportion of new subclinical infections $(P<0.001)$. However, these explanatory variables did not contribute to the final model that explains the risk of new infections.

Similarly, the ratio of chronically infected cows to cows with new cases of subclinical mastitis was influenced by almost all explanatory variables, except for the score of teat end hyperkeratosis and cleanliness of the udder. Among the characteristics evaluated, it was observed that the animals with the udder floor below the hock showed a higher proportion of chronic infections $(P<0.001)$. A significant increase in cases of chronic subclinical mastitis due to the increase of parity and DIM $(P<0.001)$ was also observed.

Similar to the occurrence of new cases of IMI, Jersey and cows with less than $20 \mathrm{~L} / \mathrm{d}$ showed a higher proportion of chronic cases of mastitis $(P<0.01$ and $P<0.001$, respectively). These explanatory variables also did not contribute to the final model that explains the risk of cases chronic. Variables with a significant effect on the occurrence of new cases or chronic cases of subclinical mastitis were selected to generate models of logistic regression, respectively, for the risk of new infections and the chronicity of an IMI.

The model that best explained the risk of a cow developing a new case of subclinical mastitis in relation to the healthy cows (Table 1 ) included the explanatory variables of parity, DIM, teat end hyperkeratosis, udder depth, and cleanliness of the udder. Cows with 4 or more parities were 1.71 times more likely to have an SCC above 200,000 cells/mL than primiparous cows $(P<0.01)$, with no significant increase in risk until the third calving. Animals between 200 to 300 DIM were less likely $(\mathrm{OR}=0.59)$ of developing a new infection $(P<0.01)$ compared with cows in early lactation. Cows with teat end hyperkeratosis (mean score above 3 points) were more at risk of new cases of subclinical mastitis $(\mathrm{OR}=1.59 ; P<0.05)$, as were cows with pendulous udders $(\mathrm{OR}=1.66)$ for cows with udder floor in line with the hock $(P<0.01)$ and 2.42 for cows with udder floor below the hock $(P<0.001)$. Cows with very dirty udders had more risk for new infections $(\mathrm{OR}=1.53 ; P<0.05)$.

The model with the best fit for the risk of an infected cow developing a chronic case of subclinical mastitis (Table 2) included the explanatory variables of parity, DIM, and udder depth. Similar to the risk of new infections, there was a higher risk of chronic infection in cows with parity 3 and 4 or more $(\mathrm{OR}=2.04$ and 1.81 respectively) compared with primiparous cows. Cows late in their lactation, despite not having an increased risk of new infection (Table 2), did have a significant increase in the risk of chronic infection, varying from 2.60 to 5.46 in different DIM $(P<0.001)$. In addition, animals with deep udders were more likely to have chronic infection than animals with shallow udders (OR $=1.48, P<0.05)$

\section{Explanatory Variables Related to Management and Milking Techniques}

Correct milking management lowered the incidence of IMI. Most of the variables related to milking management influenced the ratio of healthy cows to those with new cases of subclinical mastitis by the chi-squared test. It was observed that the properly cleaning of the teats, the removal of the first 3 streams of milk, the use of strip cup for detection of clinical mastitis, and conducting postdipping significantly reduced the occurrence of new subclinical cases $(P<0.001)$. A significant decrease in new cases of IMI was also observed with other techniques for control of mastitis, as the removal of the milking machine without pressure on the teat 
Table 1. Odds ratios (OR) and confidence intervals of new IMI according to the logistic regression model for the explanatory variables related to the individual cow characteristics, milking management, and mastitis control

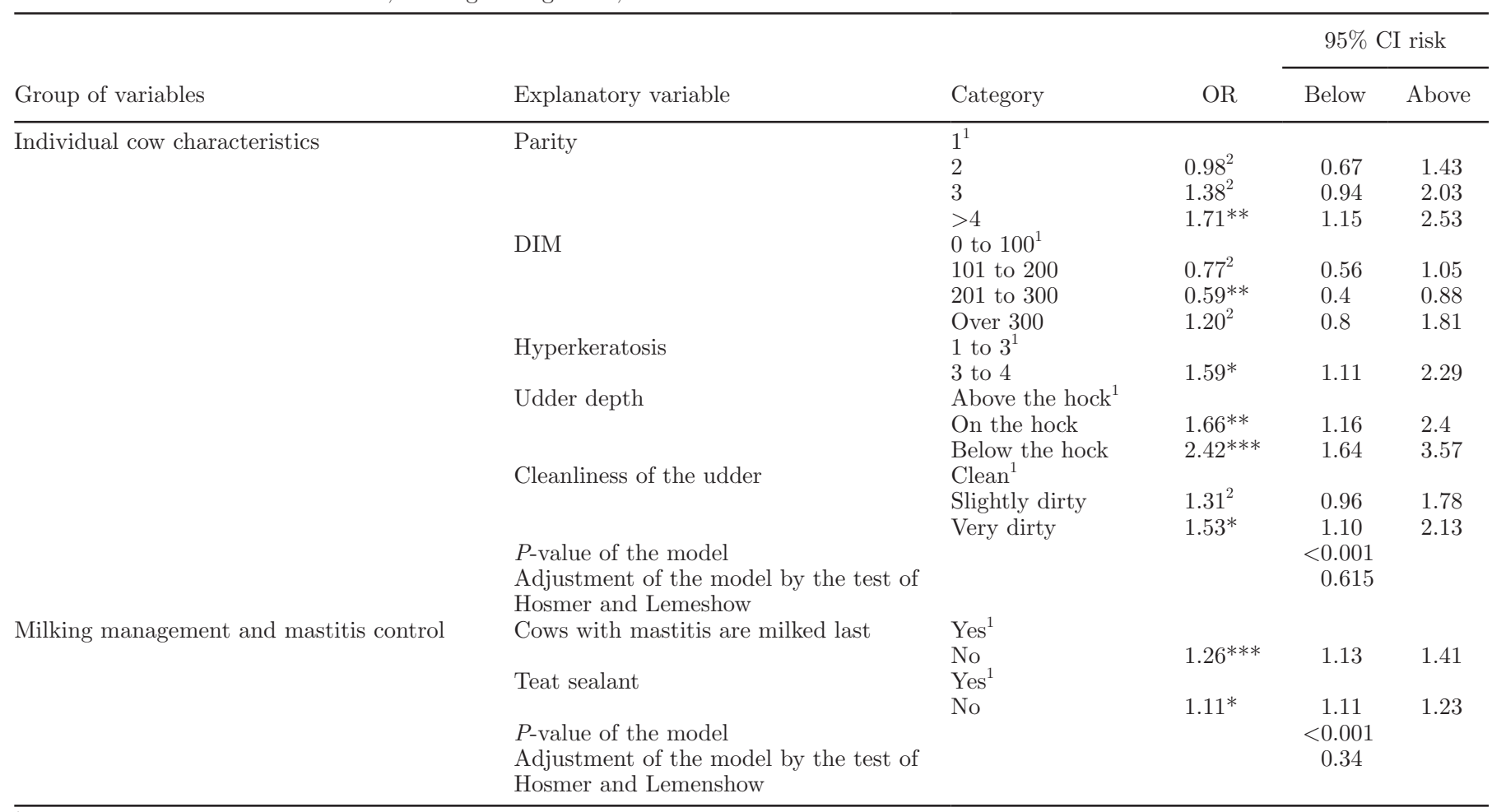

${ }^{1}$ Reference category.

${ }^{2}$ Not significant.

$* P<0.05 ;{ }^{* *} P<0.01 ;{ }^{* * *} P<0.001$.

cups $(P<0.001)$, milking the animals with mastitis last $(P<0.05)$ and intramammary use of sealant $(P$ $<0.01)$.

Conversely, most hygienic milking management and mastitis control practices had little effect on the occur- rence of chronic mastitis in relation to the new cases of subclinical mastitis. Properties that perform predipping had lower proportion of chronic cases of subclinical infections $(P<0.001)$. Procedures carried out in mastitis control, such as the milking of animals with

Table 2. Odds ratios (OR) and confidence intervals for chronic IMI according to the logistic regression model for the explanatory variables related to the individual cow characteristics

\begin{tabular}{|c|c|c|c|c|}
\hline \multirow[b]{2}{*}{ Explanatory variable } & \multirow[b]{2}{*}{ Category } & \multirow[b]{2}{*}{ OR } & \multicolumn{2}{|c|}{$95 \%$ CI risk } \\
\hline & & & Below & Above \\
\hline \multirow[t]{4}{*}{ Parity } & $1^{1}$ & & & \\
\hline & 2 & $1.44^{2}$ & 0.93 & 2.22 \\
\hline & 3 & $2.04^{* * *}$ & 1.33 & 3.12 \\
\hline & $>4$ & $1.81^{*}$ & 1.16 & 2.84 \\
\hline \multirow[t]{4}{*}{ DIM } & Until $100^{1}$ & & & \\
\hline & 101 to 200 & $2.60^{* * *}$ & 1.84 & 3.68 \\
\hline & 201 to 300 & $5.46^{* * *}$ & 3.63 & 8.20 \\
\hline & Over 300 & $4.41^{* * *}$ & 2.90 & 6.70 \\
\hline \multirow[t]{3}{*}{ Udder depth } & Above the hock ${ }^{1}$ & & & \\
\hline & On the hock & $1.41^{2}$ & 0.97 & 2.06 \\
\hline & Below the hock & $1.4 *$ & 1.00 & 2.19 \\
\hline \multicolumn{2}{|l|}{$P$-value of the model } & & $<0.001$ & \\
\hline \multicolumn{2}{|c|}{ Adjustment of the model by the test of Hosmer and Lemeshow } & & 0.187 & \\
\hline
\end{tabular}


mastitis last, the use of gloves during milking, and the removal of the milking machine without pressure on the set of liners, had a lower proportion of chronically infected cows $(P<0.001)$.

The logistic regression model indicated that the best indicating factors for the risk of new IMI were whether animals with mastitis were milked last and the use of teat sealant (Table 1). On dairy farms that did not milk cows affected with mastitis last, we observed a higher rate of healthy cows contracting new cases of subclinical mastitis $(\mathrm{OR}=1.26 ; P<0.001)$, whereas on dairy farms that did not use teat sealant we found a higher risk of new infections compared with those farms that used this preventive method against IMI during the dry-off period $(\mathrm{OR}=1.11 ; P<0.05)$. All dairy farms used intramammary antibiotic therapy for dry-off. Because the lack of fit of the model in explaining the effect of the variables in this group (model fit using Hosmer and Lemeshow test $=0.002$ ), it was not possible to generate a logistic regression model to estimate the risk of chronic infection for this group of explanatory variables.

\section{Explanatory Variables Related to Farm Structure}

All explanatory variables related to the structure of the dairy farms had a significant effect on the frequency of new subclinical IMI by the chi-squared. Among of the variables examined, we found that dairy farms with large herds had a higher proportion of new infections, especially those with production between 1,000 to 1,500 $\mathrm{L} / \mathrm{d}$ or 41 to 80 cows in lactation $(P<0.01)$. The strategy adopted by the dairy farm for the maintenance of milking equipment was also correlated with mammary gland health, with farms that performed maintenance more sporadically having a higher rate of new subclinical infections $(P<0.01)$. Regarding season, significant differences were noted in dairy cows $(P<0.001)$ for the SCC level, with a higher proportion of new cases of subclinical mastitis in summer (December to February) to those observed in spring (September to November). Farms that received bonuses for milk quality had a lower proportion of new cases of subclinical mastitis $(P<0.01)$. The effect of the vacuum line on the health status of the animals was also observed, with fewer cases of subclinical mastitis in dairy farms that used the milking machine at low line $(P<0.05)$.

Fewer variables had a significant effect on the ratio of chronically infected cows to cows with new IMI. Farms with 41 to 80 cows in lactation had a higher proportion of chronically infected cows $(P<0.001)$ than those with more or fewer cows. Furthermore, for the season, a higher proportion of chronic cases of subclinical mastitis in spring (September to November) were observed than in summer (December to February; $P<0.001$ ). We also observed a higher proportion of cows with chronic subclinical mastitis on dairy farms that performed only sporadic maintenance of the milking equipment $(P<$ 0.001) compared with those that performed maintenance regularly.

Because of the lack of fit of the model to explain the effect of the explanatory variables in this group, it was not possible to generate a logistic regression model to estimate either the risk of new IMI (model fit using the Hosmer and Lemeshow test $=0.002$ ) or the risk of chronic IMI (model fit using the Hosmer and Lemeshow test $=0.007)$.

\section{Final Logistic Regression Model}

A final logistic model for new cases of subclinical mastitis, involving all 3 groups of variables (those related to individual cow characteristics, milking management and mastitis control techniques, and farm structure) included the variables parity, teat end hyperkeratosis, udder depth, cleanliness of the udder, and milking cows with mastitis last (Table 3). Cows with 4 or more parities, as well as cows with a mean score of hyperkeratosis above 3 were at greater risk of new subclinical cases $(P$ $<0.05$ ). Cows with the udder floor below the line of the hock had a higher risk of new subclinical IMI compared with cows with the udder above the line of the hock ( $P$ $<0.001)$, with a high risk in addition for cows with the udder floor in line with the hock $(P<0.01)$. Cows with very dirty udders and dairy farms that did not milk infected animals last also had a higher risk of new cases of subclinical mastitis $(P<0.01)$.

The final logistic regression model to determine the risk of developing chronic subclinical infection in relation to the new cases of subclinical mastitis (Table 4) was composed of the maintenance of milking equipment, DIM, and udder depth. Cows with deep udders and dairy farms that performed only sporadic maintenance of milking equipment had a higher risk of chronic infections $(P<0.001)$. In addition, after $100 \mathrm{~d}$ of lactation cows had a higher risk of chronic infection $(P<0.001)$.

\section{DISCUSSION}

Strategies for the control and monitoring of mammary gland health in dairy cows are mainly designed to reduce the number of new infections, to eliminate established infections, and to decrease the duration of infections through the use of recommended techniques. Cow with high parity had a higher risk of new cases of subclinical mastitis (Tables 1 and 3), a finding in agree- 
Table 3. Odds ratios (OR) and confidence intervals of new IMI according to the final logistic regression model

\begin{tabular}{|c|c|c|c|c|}
\hline \multirow[b]{2}{*}{ Explanatory variable } & \multirow[b]{2}{*}{ Category } & \multirow[b]{2}{*}{ OR } & \multicolumn{2}{|c|}{ 95\% CI risk } \\
\hline & & & Below & Above \\
\hline \multirow[t]{4}{*}{$\overline{\text { Parity }}$} & $1^{1}$ & & & \\
\hline & 2 & $0.95^{2}$ & 0.65 & 1.38 \\
\hline & 3 & $1.34^{2}$ & 0.92 & 1.96 \\
\hline & $>4$ & $1.65^{*}$ & 1.11 & 2.44 \\
\hline \multirow[t]{2}{*}{ Hyperkeratosis } & 1 to $3^{1}$ & & & \\
\hline & 3 to 4 & $1.61^{*}$ & 1.12 & 2.31 \\
\hline \multirow[t]{3}{*}{ Udder depth } & Above the hock ${ }^{1}$ & & & \\
\hline & On the hock & $1.70^{* *}$ & 1.18 & 2.45 \\
\hline & Below the hock & $2.46^{* * *}$ & 1.67 & 3.62 \\
\hline \multirow[t]{3}{*}{ Cleanliness of the udder } & Clean $^{1}$ & & & \\
\hline & Slightly dirty & $1.33^{2}$ & 0.98 & 1.81 \\
\hline & Very dirty & $1.55^{* *}$ & 1.11 & 2.14 \\
\hline \multirow{2}{*}{ Cows with mastitis are milked last } & Yes $^{1}$ & & & \\
\hline & No & $1.55^{* *}$ & 1.14 & 2.09 \\
\hline \multicolumn{2}{|l|}{$P$-value of the model } & & $<0.001$ & \\
\hline \multicolumn{2}{|c|}{ Adjustment of the model by the test of Hosmer and Lemeshow } & & 0.826 & \\
\hline
\end{tabular}

ment with the results of prior studies (Thaler Neto et al., 2004; Olde Riekerink et al., 2007; Pinzón-Sánchez and Ruegg, 2011) simply due to the prolonged exposure to infection that comes with age (Green et al., 2008; Ruegg and Pantoja, 2013). A greater opportunity of contamination due to the conformation of the mammary gland, affecting the risk for the new occurrence of mastitis, has been demonstrated in several studies (Nash et al., 2003; Pérez-Cabal and Charfeddine, 2013; Singh et al., 2014), as well as by the results of the present study (Tables 1 and 3). Many characteristics of the conformation of the mammary gland worsen with age, especially udder depth, which can increase its contact with pathogens in manure (Peeler et al., 2000; LopezBenavides et al., 2005). Furthermore, old cows had a higher risk of chronic subclinical mastitis when the logistic regression model used only explanatory variables related to the individual cow characteristics (Table 2). However, this variable had the smallest effect on the risk of chronic infection, not making it into the final model. It should be noted that animals with a higher number of calvings tend to have more permanent injuries in the mammary gland during lactation, resulting in more prolonged infections (Bartlett et al., 1990).

Cow cleanliness is directly related to the management conditions on the farm, and cows with dirty udders had a higher risk of new infection (Tables 1 and 3), a finding in agreement with de Pinho Manzi et al. (2012), along with an increased individual SCC (Reneau et al., 2005). Consequently, keeping udders clean

Table 4. Odds ratios (OR) and confidence intervals of chronic IMI according to the final logistic regression model

\begin{tabular}{|c|c|c|c|c|}
\hline \multirow[b]{2}{*}{ Explanatory variable } & \multirow[b]{2}{*}{ Category } & \multirow[b]{2}{*}{ OR } & \multicolumn{2}{|c|}{$95 \%$ CI risk } \\
\hline & & & Below & Above \\
\hline Maintenance of milking equipment & Periodic $^{1}$ & & & \\
\hline \multirow[t]{4}{*}{ DIM } & $\begin{array}{l}\text { Sporadic } \\
\text { Up to } 100^{1}\end{array}$ & $2.17^{* * *}$ & 1.62 & 2.89 \\
\hline & 101 to 200 & $2.70^{* * *}$ & 1.90 & 3.83 \\
\hline & 201 to 300 & $5.88^{* * *}$ & 3.88 & 8.87 \\
\hline & Over 300 & $4.62^{* * *}$ & 3.04 & 7.04 \\
\hline \multirow[t]{3}{*}{ Udder depth } & Above the hock ${ }^{1}$ & & & \\
\hline & On the hock & $1.68^{* *}$ & 1.18 & 2.37 \\
\hline & Below the hock & $1.65^{* *}$ & 1.17 & 2.34 \\
\hline \multicolumn{2}{|l|}{$P$-value of the model } & & $<0.001$ & \\
\hline \multicolumn{2}{|c|}{ Adjustment of the model by the test of Hosmer and Lemeshow } & & 0.889 & \\
\hline
\end{tabular}

${ }^{1}$ Reference category.

$* * P<0.01 ; * * * P<0.001$. 
is an important prophylactic measure to take against IMI, especially by environmental agents (Dohmen et al., 2010; Elmoslemany et al., 2010). Sant'anna and Paranhos da Costa (2011) mention that the presence of dirt on cows combined with a lack of pre- and postdipping could also increase the incidence of IMI. However, in our study, udder cleanliness did not affect the occurrence of chronic mastitis, indicating that environmental conditions are more related to the initial contamination of the mammary gland (Schreiner and Ruegg, 2003).

Measures to prevent contamination from being transmitted between cows or between mammary quarters during milking are of primary importance (Harmon, 1996; Janzekovic et al., 2009). Dairy farms that did not separate the milking of infected animals had a higher risk of new IMI cases (Tables 3), although not of chronic infection, a finding also observed by Hansson and Lagerkvist (2014), who found that the milking of infected animals after healthy ones reduced the incidence of IMI. This technique is designed to prevent the contamination of uninfected animals (Barnouin et al., 2004; Ruegg et al., 2005; Hansson et al., 2011).

The number of days a cow had been in milk affected the risk of chronic subclinical infection (Tables 2 and 4), especially for cows in milk for over $200 \mathrm{~d}$, something also found by Hortet et al. (1999), Bennedsgaard et al. (2003), and Moges et al. (2012). According to Hagnestam-Nielsen et al. (2009), the increase of SCC at the end of lactation is probably due to an increased cellular response of cows to residual injuries from previous infections that result in major damage to the mammary tissue. Both Ruegg (2003) and Breen et al. (2009) found that, as lactation progresses, the opportunity for exposure to pathogens that cause IMI increases.

We found a higher risk of new cases of subclinical mastitis in the presence of hyperkeratosis (Table 3), a result similar to that of Breen et al. (2009) and de Pinho Manzi et al. (2012), whereas Bhutto et al. (2010) observed a relationship between hyperkeratosis and the presence of clinical mastitis. Among the possible causes of hyperkeratosis are inadequate pulsations of milking equipment, the removal of teat cups without removing the transfer vacuum, and overmilking (Neijenhuis et al., 2000, 2001; Barret, 2002). Defects in the milking equipment can also affect mammary gland health (Chassagne et al., 2005; Coentrão et al., 2008). Our study found that a lack of regular maintenance of milking equipment increased the risk of chronic cases of IMI (Table 4). One factor found to increase the risk of IMI was only sporadically exchanging milking liners (Peeler et al., 2000; Souza et al., 2005). Another factor was an inadequate level of vacuum, with high vacuum levels causing injuries to the teats and low levels leading to slipping of the liners (Mein et al., 2004). The pressure exerted by the liners on the skin of the teat causes an interruption in blood flow with an increase of local pressure, making small cracks that increase lesion formation at the end of the teats, leading to IMI (Mein et al., 2003).

Some milking management practices recommended for the prevention of mastitis made less of a contribution to the risk of occurrence of new cases of subclinical mastitis; whereas these were not used for the logistic regression models, they did have some effect on the incidence of IMI as judged by the chi-squared test. Correct milking management is important for the control of mastitis and for production of high-quality milk. Moreover, appropriate cleaning of teats before milking makes it harder for possible infectious agents to penetrate inside (Ruegg et al., 2005); the same is true of other recommended management practices (Rodrigues et al., 2005; LeBlanc et al., 2006). Similarly, Elmoslemany et al. (2010) found that premilking teat disinfection with subsequent drying of the teats with paper towels reduced the bacterial count in milk, whereas postmilking teat disinfection is a management technique widely known for the prevention of mastitis (Barnouin et al., 2004; Dufour et al., 2011). The use of internal teat sealant is an effective tool in the management and prevention of new IMI in the following lactation (Green et al., 2002; Huxley et al., 2002; Parker et al., 2007; Petrovski et al., 2011). The product creates a buffer, blocking the teat canal and thus preventing the entry of microorganisms into the mammary gland during the dry period (O'Rourke, 2005). In addition, the dry-off treatment of all animals helps reduce the appearance of new IMI during the dry period and during calving (Berry and Hillerton, 2002), as well as the use of teat sealant. In the present study, we observed that herds that used this tool were less likely to have new subclinical cases (Table 1), although this did not seem to affect the risk of chronic cases.

\section{CONCLUSIONS}

The main risk factors associated with the occurrence of new cases of subclinical mastitis in dairy cows were advanced age, more pendulous udders, dirty udders, presence of teat end hyperkeratosis, and not milking cows affected with mastitis after healthy cows. Factors such as cows far into their lactation, cows with deep udders, and farms that perform only sporadic maintenance of milking equipment were also associated with a higher risk of chronic subclinical mastitis. The identification of these main risk factors enables us to better prevent new cases of subclinical mastitis and to prevent new cases from becoming chronic by focusing on specific procedures for each situation. 


\section{ACKNOWLEDGMENTS}

We thank the Santa Catarina Association of Cattle Breeders (ACCB, Florianopolis, Brazil) and the dairy farmers who participated in this research for their cooperation and assistance. We also thank the Support Fund for the Maintenance and Development of Higher Education (FUMDES, Florianopolis, Brazil) of the State of Santa Catarina for financial support.

\section{REFERENCES}

Barnouin, J., M. Chassagne, S. Bazin, and D. Boichard. 2004. Management practices from questionnaire surveys in herds with very low somatic cell score through a national mastitis program in France. J. Dairy Sci. 87:3989-3999.

Barret, D. 2002. High somatic cell counts-A persistent problem. Ir. Vet. J. 55:173-178.

Bartlett, P. C., G. Y. Miller, C. R. Anderson, and J. H. Kirk. 1990. Milk production and somatic cell count in Michigan dairy herds. J. Dairy Sci. 73:2794-2800.

Bennedsgaard, T. W., C. Enevoldsen, S. M. Thamsborg, and M. Vaarst. 2003. Effect of mastitis treatment and somatic cell counts on milk yield in Danish organic dairy cows. J. Dairy Sci. 86:31743183.

Berry, E. A., and J. E. Hillerton. 2002. The effect of selective dry cow treatment on new intramammary infections. J. Dairy Sci. $85: 112-121$.

Bhutto, A. L., R. D. Murray, and Z. Woldehiwet. 2010. Udder shape and teat-end lesions as potential risk factors for high somatic cell counts and intra-mammary infections in dairy cows. Vet. J. 183:63-67.

Bradley, A., and M. Green. 2005. Use and interpretation of somatic cell count data in dairy cows. In Pract. 27:310-315.

Breen, J. E., M. J. Green, and A. J. Bradley. 2009. Quarter and cow risk factors associated with the occurrence of clinical mastitis in dairy cows in the United Kingdom. J. Dairy Sci. 92:2551-2561.

Capuco, A. V., G. A. Mein, S. C. Nickerson, L. J. Jack, D. L. Wood, S. A. Bright, R. A. Aschenbrenner, R. H. Miller, and J. Bitman. 1994. Influence of pulsationless milking on teat canal keratin and mastitis. J. Dairy Sci. 77:64-74.

Chassagne, M., J. Barnouin, and M. Le Guenic. 2005. Expert assessment study of milking and hygiene practices characterizing very low somatic cell score herds in France. J. Dairy Sci. 88:1909-1916.

Cicconi-Hogan, K. M., M. Gamroth, R. Richert, P. L. Ruegg, K. E. Stiglbauer, and Y. H. Schukken. 2013. Associations of risk factors with somatic cell count in bulk tank milk on organic and conventional dairy farms in the United States. J. Dairy Sci. 96:3689-3702.

Coentrão, C. M., G. N. Souza, J. R. F. Brito, M. A. V. Paiva e Brito, and W. Lilenbaum. 2008. Fatores de risco para mastite subclínica em vacas leiteiras. Arq. Bras. Med. Vet. Zootec. 60:283-288.

Cook, N. B., T. B. Bennett, K. M. Emery, and K. V. Nordlund. 2002. Monitoring nonlactating cow intramammary infection dynamics using DHI somatic cell count data. J. Dairy Sci. 85:1119-1126.

Cunha, R. P. L., L. Molina, A. U. Carvalho, E. J. Facury Filho, P. M. Ferreira, and M. B. Gentilini. 2008. Mastite subclínica e relação da contagem de células somáticas com número de lactações, produção e composição química do leite em vacas da raça Holandesa. Arq. Bras Med. Vet. Zootec. 60:19-24.

de Pinho Manzi, M., D. B. Nóbrega, P. Y. Faccioli, M. Z. Troncarelli, B. D. Menozzi, and H. Langoni. 2012. Relationship between teatend condition, udder cleanliness and bovine subclinical mastitis. Res. Vet. Sci. 93:430-434.

Djabri, B., N. Bareille, F. Beaudeau, and H. Seegers. 2002. Quarter milk somatic cell count in infected dairy cows: A meta-analysis. Vet. Res. 33:335-357.
Dohmen, W., F. Neijenhuis, and H. Hogeveen. 2010. Relationship between udder health and hygiene on farms with an automatic milking system. J. Dairy Sci. 93:4019-4033.

Dohoo, I. R., and K. E. Leslie. 1991. Evaluation of changes in somatic cell counts as indicators of new intramammary infections. Prev. Vet. Med. 10:225-237.

Dufour, S., and I. R. Dohoo. 2013. Monitoring herd incidence of intramammary infection in lactating cows using repeated longitudinal somatic cell count measurements. J. Dairy Sci. 96:1568-1580.

Dufour, S., A. Fréchette, H. W. Barkema, A. Mussell, and D. T. Scholl. 2011. Invited review: Effect of udder health management practices on herd somatic cell count. J. Dairy Sci. 94:563-579.

Elbers, A. R., J. D. Miltenburg, D. De Lange, A. P. Crauwels, H. W. Barkema, and Y. H. Schukken. 1998. Risk factors for clinical mastitis in a random sample of dairy herds from the southern part of the Netherlands. J. Dairy Sci. 81:420-426.

Elmoslemany, A. M., G. P. Keefe, I. R. Dohoo, J. J. Wichtel, H. Stryhn, and R. T. Dingwell. 2010. The association between bulk tank milk analysis for raw milk quality and on-farm management practices. Prev. Vet. Med. 95:32-40.

EPAGRI. 2005. Manual de referências técnico-econômicas de sistemas de produção agropecuários de Santa Catarina. Empresa de Pesquisa Agropecuária e Extensão Rural de Santa Catarina (EPAGRI), Florianopolis, SC, Brazil.

Frankena, K., and E. A. M. Graat. 1997. Multivariate analysis: logistic regression. Pages 135-178 in Application of Quantitative Methods in Veterinary Epidemiology. J. P. T. M. Noordhuizen, K. Frankena, and C. M. Van Der Hoofd, ed. Wageningen Pers, Wageningen, the Netherlands.

Gambôa, F. A. R., M. S. Caputo, and E. Bresciani Filho. 2004. Método para gestão de riscos em implementações de sistemas erp baseado em fatores críticos de sucesso. J. Inf. Syst. Technol. Manag. 1:45-62.

Geary, U., N. Lopez-Villalobos, N. Begley, F. McCoy, B. O'Brien, L. O'Grady, and L. Shalloo. 2012. Estimating the effect of mastitis on the profitability of Irish dairy farms. J. Dairy Sci. 95:3662-3673.

Green, M. J., A. J. Bradley, G. F. Medley, and W. J. Browne. 2008. Cow, farm, and herd management factors in the dry period associated with raised somatic cell counts in early lactation. J. Dairy Sci. 91:1403-1415.

Green, M. J., L. E. Green, G. F. Medley, Y. H. Schukken, and A. J. Bradley. 2002. Influence of dry period bacterial intramammary infection on clinical mastitis in dairy cows. J. Dairy Sci. 85:2589 2599.

Hagnestam-Nielsen, C. U. Emanuelson, B. Berglund, and E. Strandberg. 2009. Relationship between somatic cell count and milk yield in different stages of lactation. J. Dairy Sci. 92:3124-3133.

Halasa, T., K. Huijps, O. Østerås, and H. Hogeveen. 2007. Economic effects of bovine mastitis and mastitis management: A review. Vet. Q. 29:18-31.

Hansson, H., and C. J. Lagerkvist. 2014. Decision making for animal health and welfare: Integrating risk-benefit analysis with prospect theory. Risk Anal. 34:1149-1159.

Hansson, H., M. Szczensa-Rundberg, and C. Nielsen. 2011. Which preventive measures against mastitis can increase the technical efficiency of dairy farms? Animal 5:632-640.

Harmon, R. J. 1996. Controlling contagious mastitis. Page 11 in Proc. Natl. Mastitis Counc. Reg. Meet. Queretero, Mexico. Natl. Mastitis Counc., Madison, WI.

Hortet, P., F. Beaudeau, H. Seegers, and C. Fourichon. 1999. Reduction in milk yield associated with somatic cell counts up to 600000 cells/mL in French Holstein cows without clinical mastitis. Livest. Prod. Sci. 61:33-42.

Hosmer, D. W., and S. Lemeshow. 1989. Applied Logistic Regression. 2nd ed. John Wiley \& Sons, New York, NY.

Huxley, J. N., M. J. Green, L. E. Green, and A. J. Bradley. 2002. Evaluation of the efficacy of an internal teat sealer during the dry period. J. Dairy Sci. 85:551-561.

Jansen, J., B. H. P. van den Borne, R. J. Renes, G. van Schaik, T. J. G. M. Lam, and C. Leeuwis. 2009. Explaining mastitis incidence 
in Dutch dairy farming: the influence of farmers' attitudes and behaviour. Prev. Vet. Med. 92:210-223.

Janzekovic, M., M. Brus, B. Mursec, P. Vinis, D. Stajnko, and F. Cus. 2009. Mastitis detection based on electric conductivity of milk. J. Achiev. Mater. Manuf. Eng. 34:39-46.

Laevens, H., H. Deluyker, Y. H. Schukken, L. De Meulemeester, R Vandermeersch, E. De Muêlenaere, and A. De Kruif. 1997. Influence of parity and stage of lactation on the somatic cell count in bacteriologically negative dairy cows. J. Dairy Sci. 80:3219-3226.

LeBlanc, S. J., K. D. Lissemore, D. F. Kelton, T. F. Duffield, and K. E. Leslie. 2006. Major advances in disease prevention in dairy cattle. J. Dairy Sci. 89:1267-1279.

Lievaart, J. J., H. W. Barkema, W. D. J. Kremer, J. van den Broek, J. H. M. Verheijden, and J. A. P. Heesterbeek. 2007. Effect of herd characteristics, management practices, and season on different categories of the herd somatic cell count. J. Dairy Sci. 90:4137-4144.

Lopez-Benavides, M. G., J. H. Williamson, R. T. Cursons, S. J. LacyHulbert, and M. W. Woolford. 2005. Streptococcus uberis population dynamics in the New Zealand pastoral dairy farm. Pages 649-655 in Proc. 4th IDF Int. Mastitis Conf. Maastricht, the Netherlands. Wageningen Academic Publishers, Wageningen, the Netherlands.

Madouasse, A., W. J. Browne, J. N. Huxley, F. Toni, A. J. Bradley, and M. J. Green. 2012. Risk factors for a high somatic cell count at the first milk recording in a large sample of UK dairy herds. J. Dairy Sci. 95:1873-1884.

Madouasse, A., J. N. Huxley, W. J. Browne, A. J. Bradley, and M. J. Green. 2010. Somatic cell count dynamics in a large sample of dairy herds in England and Wales. Prev. Vet. Med. 96:56-64.

Malek, C. B., and M. V. Santos. 2008. Estratégias para redução de células somáticas no leite. Pages $65-80$ in Proc. $6^{\circ}$ Simp. Bov. Leit. Piracicaba, SP, Brazil. Fundação de Estudos Agrários Luiz de Queiroz, Piracicaba, São Paulo, Brazil.

dos Reis, C. B., J. R. Barreiro, J. F. G. Moreno, M. A. F. Porcionato, and M. V. Santos. 2011. Evaluation of somatic cell count thresholds to detect subclinical mastitis in Gyr cows. J. Dairy Sci. 94:4406-4412

Mein, G., D. Reinemann, N. Shuring, and I. Ohnstad. 2004. Milking machines and mastitis risk: A storm in a teatcup. Pages 176-188 in Proc. Natl. Mastitis Counc. Ann. Meet. Charlotte, NC. Natl. Mastitis Counc., Madison, WI

Mein, G. A., F. Neijenhuis, W. F. Morgan, D. J. Reinemann, J. E. Hillerton, J. R. Baines, I. Ohnstad, M. D. Rasmussen, L. Timms, J. S. Britt, R. Farnsworth, N. Cook, and T. Hemling. 2001. Evaluation of bovine teat condition in commercial dairy herds: 1 . Noninfectious factors. Pages 347-351 in Proc. 2nd Int. Symp. Mastitis Milk Qual., Vancouver, BC, Canada. Natl. Mastitis Counc., Madison, WI.

Mein, G. A., D. M. D. Williams, and D. J. Reinemann. 2003. Effects of milking on teat-end hyperkeratosis: 1 . Mechanical forces applied by the teatcup liner and responses of the teat. Pages 26-29 in Proc. 42nd Ann. Meet. Natl. Mastitis Counc., Forth Worth, TX. Natl. Mastitis Counc., Madison, WI.

Moges, N., T. Hailemariam, T. Fentahun, M. Chanie, and A. Melaku. 2012. Bovine mastitis and associated risk factors in small holder lactating dairy farms in Hawassa, southern Ethiopia. Glob. Vet. 9:441-446.

Nash, D. L., G. W. Rogers, J. B. Cooper, G. L. Hargrove, and J. F. Keown. 2003. Heritability of intramammary infections at first parturition and relationships with sire transmitting abilities for somatic cell score, udder type traits, productive life, and protein yield. J. Dairy Sci. 86:2684-2695.

Neijenhuis, F., H. W. Barkema, H. Hogeveen, and J. P. Noordhuizen 2000. Classification and longitudinal examination of callused teat ends in dairy cows. J. Dairy Sci. 83:2795-2804.

Neijenhuis, F., H. W. Barkema, H. Hogeveen, and J. P. Noordhuizen. 2001. Relationship between teat-end callosity and occurrence of clinical mastitis. J. Dairy Sci. 84:2664-2672.

O'Rourke, D. 2005. Assessment of cows for use of a nonantimicrobial dry cow product. J. Appl. Microbiol. 98:1256-1260.
Olde Riekerink, R. G. M., H. W. Barkema, and H. Stryhn. 2007. The effect of season on somatic cell count and the incidence of clinical mastitis. J. Dairy Sci. 90:1704-1715.

Olde Riekerink, R. G. M., H. W. Barkema, S. Veenstra, D. E. Poole, R. T. Dingwell, and G. P. Keefe. 2006. Prevalence of contagious mastitis pathogens in bulk tank milk in Prince Edward Island. Can. Vet. J. 47:567-572.

Osterås, O., L. Sølverød, and O. Reksen. 2006. Milk culture results in a large Norwegian survey effects of season, parity, days in milk, resistance, and clustering. J. Dairy Sci. 89:1010-1023.

Pantoja, J. C. F., C. Hulland, and P. L. Ruegg. 2009a. Dynamics of somatic cell counts and intramammary infections across the dry period. Prev. Vet. Med. 90:43-54.

Pantoja, J. C. F., C. Hulland, and P. L. Ruegg. 2009b. Somatic cell count status across the dry period as a risk factor for the development of clinical mastitis in the subsequent lactation. J. Dairy Sci. 92:139-148.

Parker, K. I., C. Compton, F. M. Anniss, A. Weir, C. Heuer, and S. McDougall. 2007. Subclinical and clinical mastitis in heifers following the use of a teat sealant precalving. J. Dairy Sci. 90:207-218.

Peeler, E. J., M. J. Green, J. L. Fitzpatrick, K. L. Morgan, and L. E. Green. 2000. Risk factors associated with clinical mastitis in low somatic cell count British dairy herds. J. Dairy Sci. 83:2464-2472.

Pérez-Cabal, M., and N. Charfeddine. 2013. Genetic relationship between clinical mastitis and several traits of interest in Spanish Holstein dairy cattle. Interbull Bull. 1:77-81.

Petrovski, K. R., A. Caicedo-Caldas, N. B. Williamson, N. LopezVillalobos, A. Grinberg, T. J. Parkinson, and I. G. Tucker. 2011 Efficacy of a novel internal dry period teat sealant containing $0.5 \%$ chlorhexidine against experimental challenge with Streptococcus uberis in dairy cattle. J. Dairy Sci. 94:3366-3375.

Piepers, S., L. De Meulemeester, A. de Kruif, G. Opsomer, H. W. Barkema, and S. De Vliegher. 2007. Prevalence and distribution of mastitis pathogens in subclinically infected dairy cows in Flanders, Belgium. J. Dairy Res. 74:478-483.

Pinzón-Sánchez, C., and P. L. Ruegg. 2011. Risk factors associated with short-term post-treatment outcomes of clinical mastitis. J. Dairy Sci. 94:3397-3410.

Reneau, J. K., A. J. Seykora, B. J. Heins, M. I. Endres, R. J. Farnsworth, and R. F. Bey. 2005. Association between hygiene scores and somatic cell scores in dairy cattle. J. Am. Vet. Med. Assoc. 227:1297-1301.

Rhoda, D. A., and J. C. F. Pantoja. 2012. Using mastitis records and somatic cell count data. Vet. Clin. North Am. Food Anim. Pract. 28:347-361.

Rodrigues, A. C., and D. Z. Caraviello., amdRuegg, P. L. 2005. Management of Wisconsin dairy herds enrolled in milk quality teams. J. Dairy Sci. 88:2660-2671.

Ruegg, P., and J. Pantoja. 2013. Understanding and using somatic cell counts to improve milk quality. Ir. J. Agric. Food Res. 52:101-117.

Ruegg, P., M. Rasmussen, and D. Reinemann. 2005. The Seven Habits of Highly Successful Milking Routines. University of Wisconsin, Madison, WI.

Ruegg, P. L. 2003. Investigation of mastitis problems on farms. Vet. Clin. North Am. Food Anim. Pract. 19:47-73.

Ruegg, P. L. 2006. Uso de um novo teste rápido para contagem de células somáticas. Pages 222-229 in Proc. X Novos Enfoques Prod. Reprod. Bov. Sanid. Uberlandia, Minas Gerais, ed. Consultoria Agropecuaria Junior, Botucatu, São Paulo, Brazil.

Sant'anna, A. C., and M. J. Paranhos da Costa. 2011. The relationship between dairy cow hygiene and somatic cell count in milk. J. Dairy Sci. 94:3835-3844.

Schepers, A. J., T. J. Lam, Y. H. Schukken, J. B. Wilmink, and W. J. Hanekamp. 1997. Estimation of variance components for somatic cell counts to determine thresholds for uninfected quarters. J. Dairy Sci. 80:1833-1840.

Schreiner, D. A., and P. L. Ruegg. 2003. Relationship between udder and leg hygiene scores and subclinical mastitis. J. Dairy Sci. 86:3460-3465.

Schukken, Y. H., F. J. Grommers, D. Van de Geer, H. N. Erb, and A. Brand. 1990. Risk factors for clinical mastitis in herds with a low 
bulk milk somatic cell count. 1. Data and risk factors for all cases. J. Dairy Sci. 73:3463-3471.

Schukken, Y. H., and D. J. Kremer. 1996. Monitoring udder health: Objectives, material and methods. Pages 351-360 in Proc. Herd Health Prod. Manag. Dairy Pract. Wageningen Pers, Wageningen, the Netherlands.

Schukken, Y. H., D. J. Wilson, F. Welcome, L. Garrison-Tikofsky, and R. N. Gonzalez. 2003. Monitoring udder health and milk quality using somatic cell counts. Vet. Res. 34:579-596.

Schwarz, D., U. S. Diesterbeck, K. Failing, S. Konig, K. Brugemann, M. Zschock, W. Wolter, and C. P. Czerny. 2010. Somatic cell counts and bacteriological status in quarter foremilk samples of cows in Hesse, Germany-A longitudinal study. J. Dairy Sci. 93:5716-5728.

Singh, R. S., B. K. Bansal, and D. K. Gupta. 2014. Udder health in relation to udder and teat morphometry in Holstein Friesian $\times$ Sahiwal crossbred dairy cows. Trop. Anim. Health Prod. 46:93-98.

Skrzypek, R., J. Wójtowski, and R. D. Fahr. 2004. Factors affecting somatic cell count in cow bulk tank milk-A case study from Poland. J. Vet. Med. A Physiol. Pathol. Clin. Med. 51:127-131.

Sousa, J. M. B. 2008. A hiperqueratose do canal do teto nas explorações leiteiras portuguesas. Causas e efeitos microbiológicos. Ph.D thesis. Faculdade de Medicina Veterinária, Universidade Técnica de Lisboa, Lisbon, Portugal.
Souza, G. N., and J. R. F. Brito. 2011. Fatores de risco para contagem de células somáticas. Centro de Inteligência do Leite. Retrieved May 20, 2012. http://www.cileite.com.br/panorama/qualidade14. html.

Souza, G. N., J. R. F. Brito, A. G. de Melo, G. M. Linhares, L. L. Cardozo, S. M. Hylario, and C. F. de Mendonça Júnior. 2011. Dynamics of subclinical mastitis in Holstein cows from Brazilian dairy herds with low and high bulk tank somatic cell counts. Pages 201-202 in Proc. NMC Ann. Meet., Arlington, VA. Natl. Mastitis Counc., Madison, WI.

Souza, G. N., J. R. F. Brito, E. C. Moreira, M. A. V. P. Brito, and R. R. Bastos. 2005. Fatores de risco associados à alta contagem de células somáticas do leite do tanque em rebanhos leiteiros da Zona da Mata de Minas Gerais. Arq. Bras. Med. Vet. Zootec. $57: 251-260$.

SPSS. 1998. Statistical Package for the Social Science. SPSS Inc., Chicago, IL.

Thaler Neto, A., R. Fries, and G. Thaller. 2004. Risiko-verhältnis als parameter zur genetischen Cha- rakterisierung von neu definierten merkmalen der mastitis des rindes. Zuchtungskunde 76:162-173.

Wenz, J. R., S. M. Jensen, J. E. Lombard, B. A. Wagner, and R. P. Dinsmore. 2007. Herd management practices and their association with bulk tank somatic cell count on United States dairy operations. J. Dairy Sci. 90:3652-3659. 